Revista de la red interuniversitaria de estudios sobre las literaturas rioplatenses contemporáneas en Francia

$11 \mid 2014$

De niños e infancias

\title{
Algunos poemas de Esteparia y de Grieta
}

\section{Natalia Litvinova}

URL: http://journals.openedition.org/lirico/1845

DOI: $10.4000 /$ lirico.1845

ISSN: 2262-8339

Editor

Réseau interuniversitaire d'étude des littératures contemporaines du Río de la Plata

Referencia electrónica

Natalia Litvinova, « Algunos poemas de Esteparia y de Grieta », Cuadernos LIRICO [En línea], 11 | 2014

Puesto en línea el 01 diciembre 2014, consultado el 19 abril 2019. URL : http://

journals.openedition.org/lirico/1845; DOI : 10.4000/lirico.1845

Este documento fue generado automáticamente el 19 abril 2019.

Licencia Creative Commons

Cuadernos LIRICO está distribuido bajo una Licencia Creative Commons Atribución-NoComercial-

SinDerivar 4.0 Internacional. 


\title{
Algunos poemas de Esteparia y de Grieta
}

\author{
Natalia Litvinova
}

\section{NOTA DEL EDITOR}

Natalia Litvinova, Gómel, Bielorrusia, 1986. Reside en Argentina desde los 10 años de edad. Es poeta y traductora de poetas rusos. Publicó Esteparia (Ediciones del Dock ; Ártese quien pueda ; Trópico Sur Editor ; Llantodemudo ediciones), la plaquette traducida al francés, Balbuceo de la noche (Melón editora), Grieta (Gog y Magog ediciones,) la antología Cortes invisibles (Editorial Letras de Cartón), Rocío animal (La Pulga Renga) y Todo ajeno (Vaso roto). Compiló y tradujo las antologías El ruido de la existencia (Editorial Leviatán) de los poetas rusos Jodasevich y Esénin, El espejo equivocado (Melón editora) de Cherubina de Gabriak y la antología de Innokenti Ánnenski.

\section{FUGAS}

1 la lengua me lleva por los ríos turbulentos de la infancia. la infancia no me vio crecer, me construí con las sobras de la marea alta.

\section{A ESCONDIDAS}

2 El sol rompía sus rayos contra las hojas de la parra. La luz verde clara en mis ojos como salvación. Viva o muerta. 
Las manos del sol subían por mis piernas.

Los padres no estaban. No habían nacido aún.

El movimiento de la naturaleza se encargó de eso.

\section{EL DÍA QUE NACÍ}

recuerdo el día que nací.

llovía y los árboles soltaban todos sus frutos, la fertilidad de los ríos era capaz de matarnos.

recuerdo el día que nací.

tenía los ojos ciegos, la boca muda y el alma intocable.

mi padre me prestó su mano para que yo no supiera qué hacer con ella.

amo las manos de mi padre, origen de toda creación y de la fe.

recuerdo los abismos del vacío, los límites, el calor del alba sobre mi nuevo rostro.

mis manos extendidas al no saber.

\section{NO CREZCAS}

4 vuelvo a tener la edad que nunca tuve.

mi padre se acomoda sobre mi regazo

y me susurra al oído su regalo de navidad.

acaricio sus cabellos.

no crezcas

eso no hace falta para que exista.

él insiste y crece.

ahora un cuerpo sobra.

\section{MANO}

5 acariciá a tu hija

que pide una docena de guerras

como rosas tachadas

para recomponer su cuerpo 


\section{CEREMONIA}

6 la infancia

te hará un palacio de invierno,

sembrará tus verduras,

será tu pájaro

recortado del periódico.

una castaña vista

desde la ventanilla del colectivo.

quemará la casa.

venderá tu fruto.

cortará al pájaro

adherido a la nieve. 